\title{
"Servitization" Coupled With "Globalization": A Solution Oriented Business Strategy for Japanese IT Manufacturer towards Emerging Market Entrants
}

\author{
Zahir Ahamed $^{1}$, Akira Kamoshida ${ }^{2}$ and Takehiro Inohara ${ }^{1}$ \\ ${ }^{I}$ Tokyo Institute of Technology, , Ookayam, Meguro-ku, Tokyo, Japan \\ ${ }^{2}$ Kyoto University, Yoshida Hon Machi, Sakyo-ku, Kyoto, Japan
}

\begin{abstract}
The term 'servitization' adding value by adding services is not new any more in the manufacturing industries of developed economy, like as Japan. But, it is still new or in many cases unknown in the developing economy, such as Bangladesh. 'Globalization' is another keyword in this paper well known by almost every economy since it is witnessed as a modern form in $19^{\text {th }}$ century. But recently, the significance of this term increases couple of times in Japanese manufacturing industries, namely, in the IT industry, because of, shrinking domestic market, razor margin, and sometimes-poor performance against rivals. In this context, companies are seeking opportunities in the global IT market, particularly in Southeast Asian countries. At the same time, the emerging country like, Bangladesh is looking more value added goods and services suppliers in the IT industry who offer 'total solutions' and 'know-how'. Thus, the purpose of this paper is to present the opportunity and challenges for Japanese IT manufacturer towards emerging market entrants, such as, Bangladesh. A conceptual model is then proposed, in which Japanese IT manufacturer pursue its capabilities by aligning with local partner and create values for each other. The paper uses an exploratory single-case study approach based on semi-structured interviews, and archival data. A total of 28 in- depth interviews were conducted both in the case company, i.e., Fujitsu and Bangladesh IT industry, resulting in more than 100 pages of interview data. The survey result shows the high potentiality and key challenges for Fujitsu in Bangladesh market. These challenges are long time process for business establishment, high-capability of multi vendor products, and creating brand awareness. Moreover, this research provides insightful information to understand, analyse and plan to move Bangladesh IT market strategically.
\end{abstract}

Key Words: ICT industry, servitization, globalization, emerging country, process orientation, business innovation, technology management

\section{Introduction}

Servitiation or globalization both is highly recognized in manufacturing industries, particularly in developed economy. The concept of servitization 'adding value by adding services' was first introduced by Vendermerwe and Rada (1988), which in later has come under spotlight both in academic and business. The application of this concept has been observed in Japanese industries in late 1990s. Since then, the trend of servitize firms in this industry has tremendously increased and reached close to 30 percent in 2008 (Neely, 2007). But, why the manufacturer quickly jumped to servitize? From customer perspectives, users have started to desire more services beyond physical goods or need packaged services encompassing goods. They do not simply want to buy a computer or server; they also want solutions and guarantee that it works. They want ease of use, maintenance, repair, support, and knowledge how it works better. On the other hand, from supply side perspectives, such changes mean that suppliers cannot satisfy customers merely with physical goods, differentiate themselves, and gain their desired profit any more. Thus, the firm frequently implements servitization strategy, because of financial benefits, i.e., revenue stream and profit margin, strategic advantage, i.e., competitive opportunities, and marketing drivers, i.e., customer relationship and product differentiation (Mathe, \& Stuadacher, 2004; Gebauer, \& friedli, 2005; Oliva, \& Kallenberg, 2003).

Globalization is another key word in this paper that refers to the deepening of economic ties worldwide resulting from intensified cross-border movement of capital and labor force, increased transactions of commodities and services through trade and expanded overseas investment (Annual Report on The Japanese Economy and Public Finance, 2004). Japanese corporations in this regard are enjoying the advantage of globalization since in late $1980 \mathrm{~s}$, and they have still high potential to benefit from it more than enterprises in any other country. In realizing the potentiality and 
economic pressure, such as, a cutthroat competition, razor margin, and shrinking domestic market, many companies are looking the opportunity in global market, particularly in emerging country. Consequently, the commoditization and high production costs increased their attention and add pressure to think 'globalization' as one of their core strategies. In this context, one of the best scenarios is to invest to transform their global operations and to expand globally, more specifically the Southeast Asian country. This will enable the Japanese firms to capture growth markets by leveraging their multinational infrastructure and know-how. They also can take advantage of lower cost global talent to increase operational efficiency and profitability as well. But, questions may arise in the beginning of discussion in every organization; where they go? And how they go?

In order to provide the answer of these questions, we primarily analysis the current market growth of Southeast Asia and picked the country Bangladesh as one of the possible destination for investment in IT field. At the same time, we adopted a case study of Japanese IT firm, referred to as Fujitsu Limited, which can be qualified in its industry as a large size organization with yearly sales of JPY 4467 billion in fiscal year 2012 (Fujitsu Annual Report, 2012). It is observed that while the concept of servitization is fully adapted in Japanese hi-tech manufacturing, like Fujitsu limited and globalization has become their core strategy, there is no discussion and/or application of this concept as a value addition process to the emerging country, such as Bangladesh. Therefore, this paper will examine how Japanese company, i.e., Fujitsu can tie and / or enter into Bangladesh market and create values for each other.

The paper is organized as follows. After the introduction, research methodology is explained. The next section describes how servitization coupled with globalization and create values for Japanese IT manufacturer towards emerging market entrants, such as Fujitsu in Bangladesh. After then the background of Bangladesh IT market is discussed, including, supply chain, needs and problems. It is followed by the potentiality and challenges for Fujitsu in Bangladesh IT market in the next section. The guideline for Fujitsu entering in Bangladesh IT market is provided then, including business strategy, and partnership alliance. In later, we proposed a conceptual business model of partnership alliance and showed how it can create values for both Fujitsu and local partner. The next section we discusses the research output is presented in this article. Finally, the article concludes with further research area and questions.

\section{Research Methodology}

The methodology used in this paper was interviews and discussions with the employees of Fujitsu limited and suppliers, System Integrators (SIers), and the end users of Bangladesh IT market. We conducted a total of 28 in-depth interviews, separated into two distinct phases. Each of the interviews lasted between 60 and 90 minutes, and was recorded and subsequently transcribed verbatim. The initial exploratory stage commenced in August 2012 by the engagement with Fujitsu limited over two months internship period. In this stage, we analyzed the company's current business trend and conducted 11 semi-structured interviews specific to the issue of globalization. The interviewees were designated as a director, vice president, senior managers, managers, coordinators and officers of portfolio strategy and integrated marketing unit. The questions asked in this stage about the respondent's perception and tendency of firm movement toward emerging market entrants, particularly in Bangladesh. It is also discussed as a group seminar when, why, and how they think to penetrate this particular market.

The second phase of the research was composed of a further 17 semi-structured interviews carried out in December 2012. The interviewees in this phase were included IT goods suppliers, service engineers or / and systems integrators (SIers) and end users of Bangladesh IT market. The questions were asked to the respondents about current process of supplying goods, services offering, difficulties face in supply chain system, and customer satisfaction or interaction level between suppliers and end users. The survey result shows that product suppliers or sellers cannot meet the customer needs due to the current business model and/or process, market condition, and infrastructure as well. It also reveals that end users are not happy anymore with products only, they also want 'total solutions', i.e., consulting, maintenance and support, and training and knowledge services.

\section{'Servitization' Coupled With 'Globalization': Scenario Analysis}

Since in late 1990s, there has been a significant trends observed in Japanese manufacturing industries that the firms are shifting their business from not only producing goods to offering an integrated package of goods and services. The term 'servitization of business' was coined to describe this movement. Today, it is widely recognized as a competitive business strategy in Japanese manufacturing industry. Many leading firms, such 
as, Fujitsu in 1999, implemented this strategy to improve their competitive advantage, environmental sustainability, and differentiate them from competitors who simply offer lower priced products.

But, recently there is a new issue and / or tension has come into Japanese industries' top discussion and so often heard a common slogan 'Go Global'. Almost, every organization, particularly high-tech firms want to expand their business and increase global market share significantly. The reason behind of this commonality is shrinking domestic market, cutthroat competition, razor margin, and sometimes-poor performance against rivals in the industry. In this context, companies are looking low cost, quick return and less competitive marketplace where high-tech industries, such as, IT

is not matured yet. Consequently, Japanese firms focus on Southeast Asian countries where IT is growing rapidly. In these circumstances, the emerging country, like, Bangladesh is ahead in IT growth and realized most thrust sector than any other sectors in the industry. While Bangladesh is looking more reliable and value added suppliers who not only provide goods but also services as a solution, Japanese firms, like, Fujitsu is finding opportunity for IT investment toward Southeast Asian countries. This timing of the demand of both parties, i.e., Bangladesh IT industry and Japanese firms create values, which we portrayed in the following Figure1.
Current Status

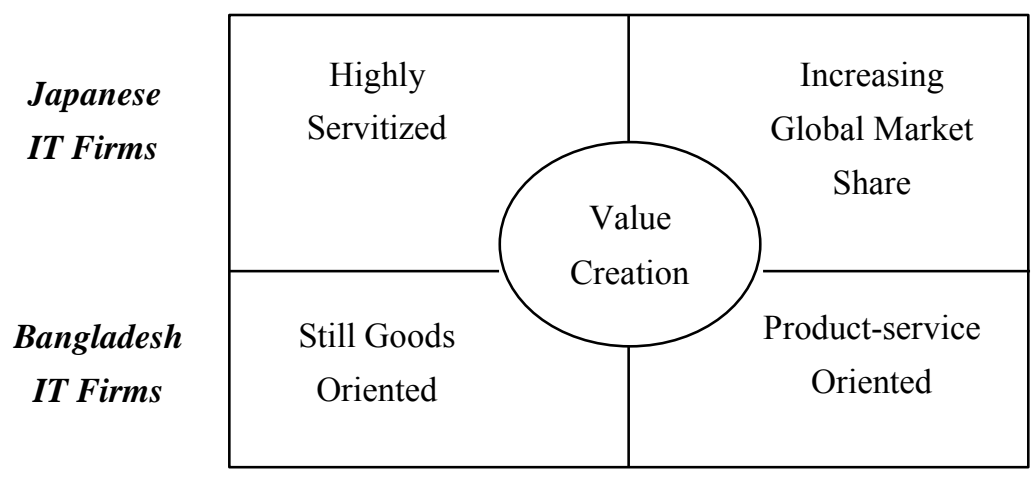

Figure 1. Hypothetical model where values are created
In Figure 1, it is observed that Japanese IT firms are currently recognized as servitized and realize to increase global market share that becomes one of its core strategies. On the other hand, firms in Bangladesh IT industry are still goods oriented and they want to be service oriented in response to customers' needs and expectations. In this regard, both parties demand are interdependent and meet one point that creates values for each other. In order to show the feasibility of this article and easy to understand of the readers, we adopted a single case study, referred to as Fujitsu Limited, Japan. The company is highly recognized as a productservice provider in the IT industry and attempting to enter into Bangladesh market. The next section gives an overview of company's business and movement toward global expansion.

\section{Case study: Fujitsu limited}

Fujitsu limited, a leading Japanese IT firm was established in 1935, as the manufacturing subsidiary of Fuji Electric limited. At the beginning of the journey, company started to produce telephone and automotive exchange equipment and steadily expanded its activities in producing computers, semiconductors, and telecommunications equipment and so on. Historically, Fujitsu was best known as the world's number 2 maker of mainframe computers, just behind IBM, but they exited from that market at the turn of the millennium to focus its hardware efforts on Unix-based servers, personal computers, and peripherals. In the early $21^{\text {st }}$ century, however, the firm was deemphasizing its hardware roots, billing itself as an internet-centered company, and generating increasing amounts of revenues from services and software. The later, which included such areas as system integration services, front-end technologies, outsourcing services, network services, system support services, security solutions and consulting services. As a result, they achieved over 50 percent of revenues from the provision of services that are closely coupled to its products. The company has made a significant progress and is at a relatively advanced stage of product-service 
operation, i.e., servitization in the IT industry. This was confirmed by the Vice-President of Portfolio and Marketing Strategy who comments that, "at the interfaces between the company and customers, I think we are now seeing far more evidence of responsive agile service-centered behavior and solution oriented to the customers, so it is the time to seek global opportunities, especially those countries where services are becoming important". Thus, we picked the emerging country Bangladesh and analyzed the potentiality of IT business for Fujitsu in this market. The next section explains the background of Bangladesh IT industry, including, supply chain, problems and desire customer needs.

\section{Background of Bangladesh IT Market}

Bangladesh is one of the next 11 emerging countries in the world, just after the BRICS (Goldman Sachs, 2005). The country has more than 160 million populations with GDP growth rate approximately 6.6 percent, i.e., world's $5^{\text {th }}$ position in fiscal year 2012 (World Bank).

During the late 1990's, Bangladesh has seen an increasing growth of the IT industry. Initially, the favorable tax policy of the government of Bangladesh in 1998 accompanied by the global affordability of personal computers have had tremendous impact on the usage of computer. The favorable import tax policy on computers and computer accessories during that time was one of the timely steps taken by the government of Bangladesh. From then on, in accordance with the global trends, both private and public sectors in Bangladesh caught up with effective utilization of information technology. However, the big revolution of IT industry in Bangladesh has been observed in 2008 when the new government was elected and envisioned to create a "Digital Bangladesh" by 2021. In this context, with government IT supportive policies, many automation projects such as e-governance projects are implementing continuously that increases the demand for IT services in Bangladesh. Consequently, many large-scale automation projects have been implemented in telecom, banking, and garment/textile sectors and domestic demand for software and IT Enabled Services (ITES) increased rapidly. As a result, today the size of the IT market in Bangladesh is estimated to be around $\$ 3.2$ billion excluding telecom, i.e., more than $\$ 3.0$ billion, in which 61 percent comprises by hardware, 29 percent by software, and 10 percent by ITES approximately (WEF; BASIS; Gartner; IDC, 2012). According to Gartner, Bangladesh is among the world's best destinations for IT outsourcing in-terms of cost. The country offers an attractive cost proposition, given its low salary levels and low cost of living that took into the account for rating the country as an ideal destination. Consequently, an educated, trainable and young workforce working in Bangladesh IT sector possesses the required skill sets to compete in the global scenario.

\section{Analyzing current market: Supply chain, problems, and needs}

The IT industries of Bangladesh comprises distributors, dealers, resellers of computer and allied products, locally assembled computer vendors, software developers and exporters, internet service providers, IT based educational institutions and training houses, IT embedded services providers, and so on. In this section, we analyze the current value chain of supplying goods, problems associated with this system, and the desired needs of customer toward IT goods supplier or reseller. The following Figure 2 represents the current supply chain system that we portrayed based on the interview results and discussion with suppliers in Bangladesh IT industry.

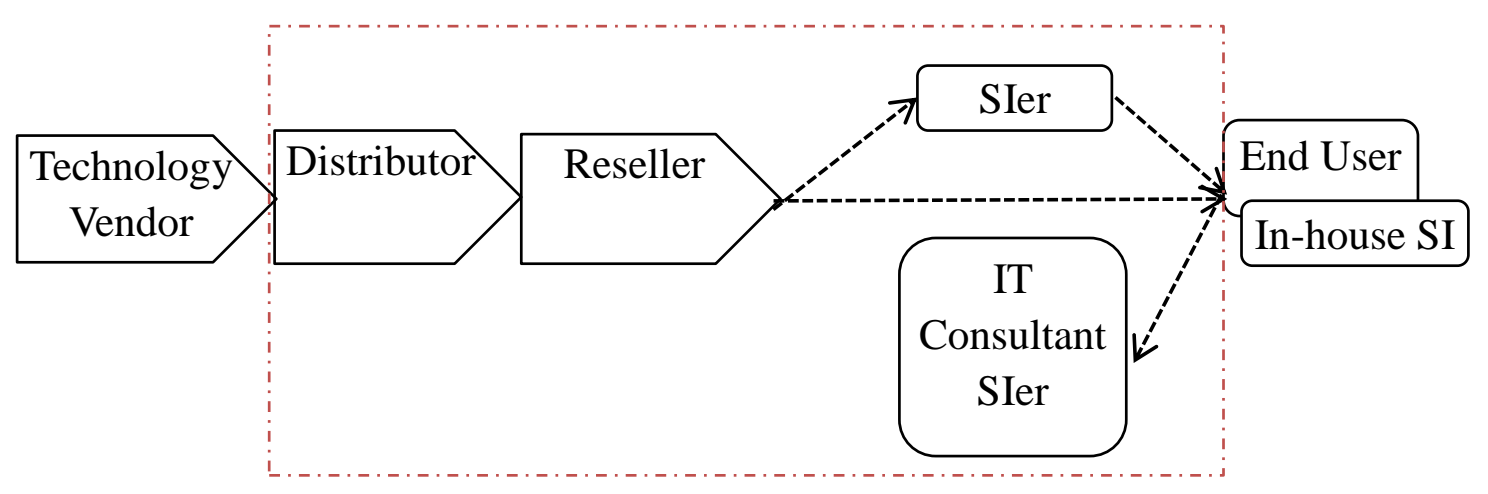

Figure 2. Product supply chain system in Bangladesh IT market. 
In Figure 2, it is showed that the current products supply chain process takes many steps to reach the products on end user's hand, which observed many disadvantages and low values from customer perspective. The problems identified in this supply chain are indicated by red dash, such as, lengthy process, i.e., high lead-time, margin on margin in every step, and less reliability of goods and services. In addition to these, customers cannot get any other services depend on hardware or nonhardware, i.e., service-ware except warranty. They meet these needs through $3^{\text {rd }}$ party service providers, i.e., SIer or sometimes their in-house system integrator (SI), which incurred high cost and time. In this context, majority of customers want these services with products from one-space rather than move to different door, such as, consulting, training, maintenance services and so on. More specifically, the key customer needs are identified in the following based on interview and discussion with end users.

- Consulting services, i.e., pre-sales services. For example, if a customer decided to buy a server, they require the configuration of the server or pre-verified template before the final purchase of the product.

- Support and maintenance services, i.e., after sales services. Customers want the guarantee of the products that it works better and quick replacement or recovery in case of any problems during the warrantee period.

- Technical assessment, i.e., periodical check. Customers want periodical assessment of their systems or products that it performs appropriately.

- Other services, such as training and/or knowledge about the products or handling the systems to gain better performance.

Thus, it is observed that the necessity of integrated goods and services provider in Bangladesh IT market is crucial. In this regard, the solution oriented business model seems very important and assumed to create values for both customers and suppliers in long-run business perspective.

\section{Fujitsu in Bangladesh Market: Opportunity vs. Challenges}

1.1. ICT in Bangladesh is not saturated yet in comparison to other business sectors, such as garments, banking and telecom industry. The unlimited potential of the IT sector has commended inquisitive interests from all concerned. The impact of global hype of the IT sector is clearly visible in Bangladesh as well. In the recent years, the local and foreign investors in IT industry have grown enviably. The favorable government policy for the IT industry, such as $100 \%$ duty free of IT goods and services, tax exemption for investors and financial support to the new entrepreneur is attracting these investors toward this sector (BCS; MOICT, 2012).

In terms of cost effectiveness, it is observed that while cheap labor is the biggest competency for the Bangladesh ICT industry, many Japanese IT firms, like, Fujitsu is in under cost pressure that remain profit margin significantly lower than their global peers since long time. In this context, Bangladesh is a potential marketplace for Fujitsu that they consider to move forward. However, in recent times, the country has become one of the prominent outsourcing destinations in the world that Fujitsu can easily venture into this readily available opportunity. The telecom boost in the country presents another opportunity for Fujitsu as support service to the telecom companies. The major focus of the telecom opportunities lie in the form of mobile content development and value added service solutions. The government is yet another big opportunity that is worth pursuing. To act on its declaration of IT as 'thrust sector', the government is seriously taking initiatives towards public IT projects. The focus of these projects is in the form of e-governance and office automation. In addition to these, garments, banking, financial institutions, SME and agriculture sector for cloud application show the potentiality for Fujitsu in Bangladesh IT market. Moreover, the industry experts opined that the geographical location of the country is suited to reach out to other markets in Southeast Asia.

Although, Bangladesh IT industry has many right ingredients for success, there are some challenges or threats observed in this industry is as follows:

- In Bangladesh, the process of legally establishing a company or partnership alliance takes long time. It can take up to six months to obtain the necessary licenses, approvals in case company establishment.

- The management style in Bangladesh is largely based on a top-down approach, which is opposite from Japanese style i.e., bottom-up approach where each person is responsible for its own job - it also means that Bangladesh is short of middle management skills.

- Bangladesh peoples do not see the Japanese firms, like, Fujitsu as a computer or B-to-B company.

- High capability of multi-vendor server, limited budget for software, software piracy, and slow networks are another obstacles for Fujitsu to expand the business in Bangladesh market. 
Moreover, entering the Bangladesh IT market will help Fujitsu in expanding their business and achieve cost effective benefits. In long run perspectives, Fujitsu can venture into other potential Asian markets and capture the agriculture and SME market niche in Bangladesh as well as other regions.

\section{Business Strategy for Fujitsu in Bangladesh Market}

As it is discussed in the beginning of this article that Japanese companies are eager to move global marketplace, especially in Southeast Asian countries, but the questions always come into front; how they go? This is not only in the IT industry, but also in every industry. For an example, we attend an event of Japanese drinks company, namely, ITOEN Company Limited, which is currently considering their business toward global expansion. We asked to the president of this company about their business plan toward Asian market, particularly, in Bangladesh and he commented "we want to go, but the critical thing is how we go?" So, this is very common 'Go but How' in the Japanese industry nowadays, and therefore next section finds the way for Fujitsu how they can move toward Bangladesh IT market.

\section{Roadmap to Market Entrance}

The most important and critical task is to set up the right strategy and/or roadmap for target market entrance. After analyzing the current market situation and customer needs, we draw the following roadmap in Figure 3, which gives some essence to Fujitsu how they can enter to Bangladesh IT market. We divided the market in various phases based on current customer needs and projected demand in future.

In Figure 3, it is suggested the firm to enter into Bangladesh IT market by approaching goods and related services as a solutions in the 1 st phase, i.e., PCs, server, storage, consulting, training, and so on. After then the firm can gradually extend it's businesses based on customer needs, such as, software and other solution services in phase 2 , cloud computing and/or big data in 3rd phase, and outsourcing in future phase. In addition to these, Fujitsu can develop their offshore capability in Bangladesh, which is very effective in terms of cost and quality that increase its competitiveness in the global IT world.

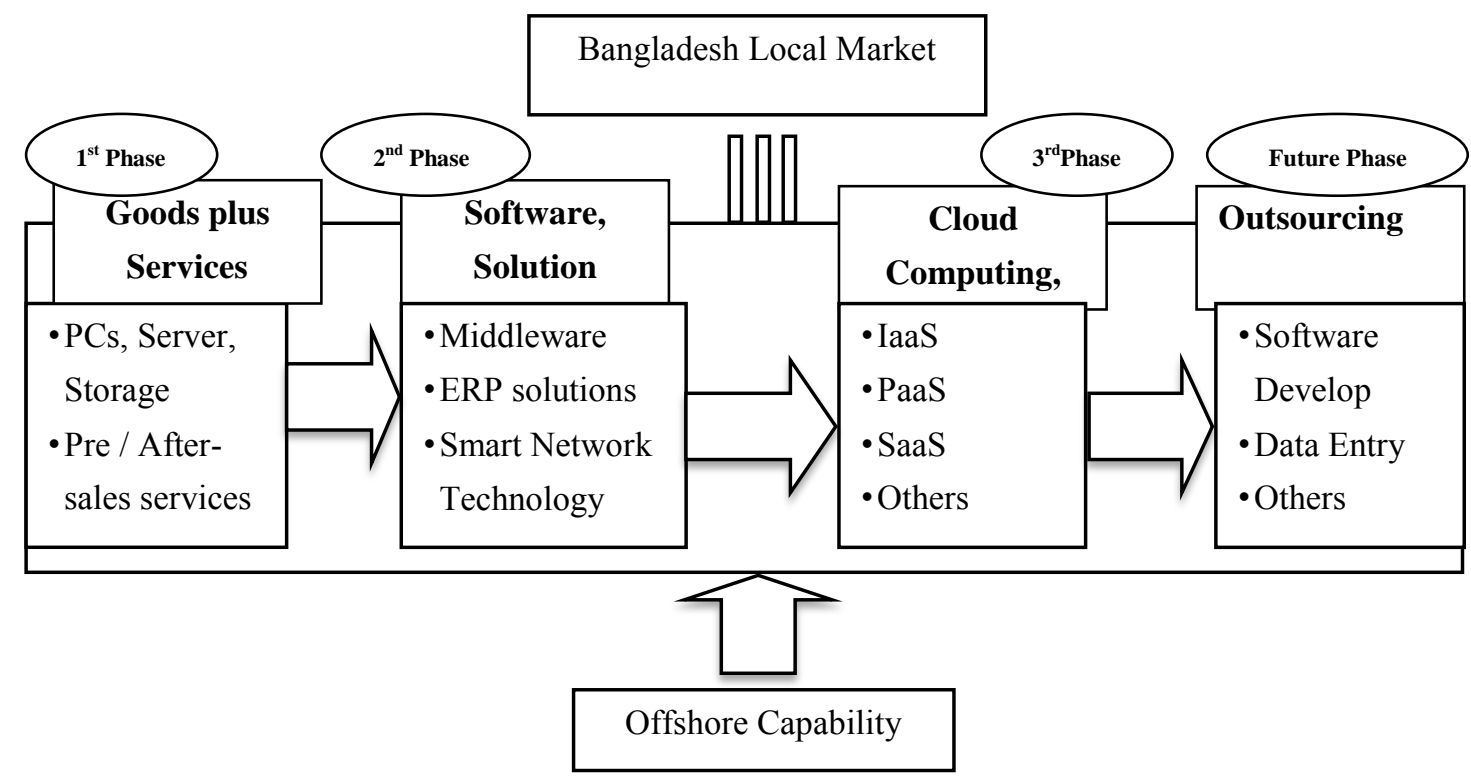

Figure 3. Roadmap for Fujitsu toward Bangladesh IT market.

\section{Partnership Alliance}

In this section we tried to select the right partner for Fujitsu, which is most important but difficult. We first identified the dominant value added resellers or/and system integrators (VAR/SIer) in Bangladesh IT market, and then selected two potential partners based on strategic and economic viewpoint. A summary table of the most dominant VAR/SIer is stated in the following: 
Table. 1. Dominant VAR / SIer in Bangladesh.

\begin{tabular}{|c|c|c|c|}
\hline VAR / SIer & Business Portfolio & Partner / Certification & Partner capability \\
\hline $\begin{array}{l}\text { Dohatec New } \\
\text { Media }\end{array}$ & $\begin{array}{l}\text { Web applications, Database development, } \\
\text { CD-ROM based application }\end{array}$ & Microsoft & \\
\hline Leads Corporation & $\begin{array}{l}\text { Custom application software development, } \\
\text { Network infrastructure building, Servers, } \\
\text { POS, and ATMs }\end{array}$ & $\begin{array}{l}\text { Capability Maturity Model } \\
\text { Integration (CMMI), } \\
\text { DataCard Group, Dell, NCR }\end{array}$ & \\
\hline Spectrum & Identity and Security, Midmarket & Microsoft, NetApp, CISCO, & \\
\hline $\begin{array}{l}\text { Engineering } \\
\text { Consortium Ltd. }\end{array}$ & Solution Provider, Server Platform & Oracle, Emerson, (CMMI) & $\sqrt{ }$ \\
\hline $\begin{array}{l}\text { Takral Information } \\
\text { Systems Pvt. Ltd. }\end{array}$ & $\begin{array}{l}\text { IT Systems Integration, IT consulting, } \\
\text { Onshore and Offshore Outsourcing } \\
\text { Services, Marketing and Distribution, } \\
\text { Logistic services. }\end{array}$ & Microsoft, IBM & \\
\hline $\begin{array}{l}\text { Datasoft Systems } \\
\text { Bangladesh Ltd. }\end{array}$ & $\begin{array}{l}\text { Custom software, MIS solutions, Business } \\
\text { applications, E-commerce solutions, Web } \\
\text { application, Networking. }\end{array}$ & $\begin{array}{l}\text { TEMENOS, NAVIS, } \\
\text { ELITECORE, COSMOS, } \\
\text { GROUPECARE, iMEDIA, } \\
\text { PROGRESS TECHNOLOGY, ST } \\
\text { ENGINEERING, (CMMI) }\end{array}$ & $\sqrt{ }$ \\
\hline $\begin{array}{l}\text { SouthTech Limited } \\
\text { Bangladesh }\end{array}$ & $\begin{array}{l}\text { IT consultancy services, Customized } \\
\text { software development, Solution services }\end{array}$ & $\begin{array}{l}\text { Microsoft, IBM, Oracle, } \\
\text { PROMETRIC, PERFEXTECH }\end{array}$ & \\
\hline
\end{tabular}

From the above Table 1, we selected two best partners, namely Spectrum Engineering Consortium Limited (2012), and Datasoft Systems Bangladesh Limited (2012). The reasons behind of choosing these partners are as follows:

- Certified IT services provider in Bangladesh (Capability Maturity Model Integration).

- Expert in telecom and banking solutions services (Partnership with TEMENOS, Switzerland).

- Many IT partners around the world that can make opportunity for Fujitsu to develop its business channel in those markets.

- Reliable and easy to approach through Fujitsu existing partners: CISCO, Oracle, and Microsoft.

- No partnership alliances with major IT vendors in the market

- Good business channel and relationship with clients in varsities field, including, telecom, financial, government, manufacturing, real estate, and so on.

It is expected that if Fujitsu can make a partnership alliance with one of these two partners, then the possibility of success is very high. Thus, it is suggested the firm to enter market quickly.

\section{Proposing Business Model for Partnership Alliance}

In the earlier section, we observed that Bangladesh IT market is not matured yet and the product supply chain system still seems complex. The customers have to go many doors in order to get their desired needs. The transactions happened in this market basically product selling that observed low values and lack of customer expectations fulfillment. In this context, we developed the following conceptual model (Figure 4), i.e., solution selling approach, in which Fujitsu and local partner can jointly create values for Bangladesh IT customers as well as for them. However, in this process, Fujitsu and local partner both will be benefitted from strategic and financial viewpoint.

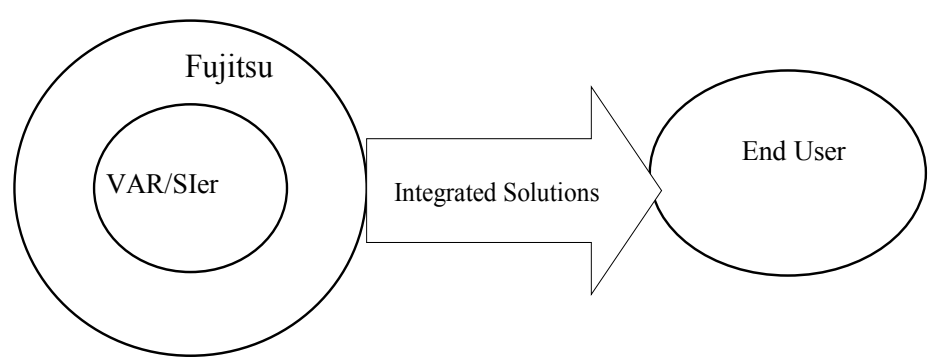

Figure 4. The conceptual model for partnership alliance 
The Figure 4 represents how Fujitsu and local value added reseller/system integrators (VAR/SIer) can combinable meet the customers' needs. Instead of trying to sell the items only or services as an add-on, the model addresses to solve the customers' problems by offering integrated solutions. It is often concluded that the hardware only part of the solution. But, it is not necessary in every aspect and more ethically the 'solution' meaning is to solve the customer problems, which can be goods or services and/or both that fulfillment the desire customer needs.

In this business model or partnership alliance, both Fujitsu and local partner can create values for each other. While Fujitsu deliver the high values of goods and services to the local partner, such as, success story/business model, IT knowledge/ training, and Japan quality brand, at the same time local partner support to the Fujitsu by solving the legal issues required to do business in Bangladesh market. The local partner also can increase the brand awareness in local market, handling the customers in local language, and offering more customized goods and services. Moreover, in this business model, the customers do not have to go many places for their needs fulfillment; they can get everything as a bundle, i.e., goods and services from one space, which are values for customer in terms of cost, simplicity, time and reliability as well.

\section{Discussion}

The concept of servitization or product-service operation strategy is already adapted in Japanese hi-tech industries, such as, in IT industry. Today, the key concern of this industry is to increase global market share and how to deliver its capabilities of product-services systems to emerging country where services become more important and/or IT is still immature. The objective of this article is to seek an ideal destination for Japanese IT manufacturer, such as, Fujitsu limited toward Southeast Asian market. After reviewing the emerging country, i.e., high growing IT market in Southeast Asia, we found the potentiality of Bangladesh IT market is better than many other nations in this region. The necessity of products and services as a 'bundle' in this country is becoming crucial. The key services identified in this market are solution services, such as, consulting, support and maintenance, technical assessment, knowledge, and training. The paper also proposed a conceptual model by which Japanese IT firm, i.e., Fujitsu can alliance with local partner in Bangladesh and create values for IT industry as a whole.

Thus, the real value of this article is presented for Japanese firms and local supplier and customers of Bangladesh IT market. For Japanese IT firm who do see their IT capability is key to expand the business to Bangladesh market, it is very informative and helpful to understand the current market condition and customer needs as well. On the other hand, local suppliers in Bangladesh will be benefited in long run business perspective. Consequently, it will reduce the cost of goods, minimize transaction time, and increase the reliability of goods and services, which makes the customers in Bangladesh IT market more satisfied and loyal to suppliers.

\section{Conclusion}

Servitization is an organization's innovation of creating values by adding services with existing offerings. In this article, we observed that the concept of servitization strategy is highly adapted in Japanese manufacturing industry during last decade, particularly in information technology (IT). Nowadays, this industries' main focus is to increase global market share by using its productservice systems capabilities, i.e., 'know-how'. One of the big reasons of industries' global tendency is the prediction of local market size shrinking. Consequently, the commoditization, high cost, and cutthroat competition also added the massive pressure in Japanese industry in comparison to global rivals. In this context, the best scenario realizes in the industry is to move global market, specifically low cost emerging market. Thus, this article shows the possible marketplace for Japanese IT firms to expand their business, and identified the way of entering that market properly. As some part of this research is completed through an engagement with the Japanese IT firm, referred to as, Fujitsu limited, we have got chance to observe closely of firm tendency toward global expansion, i.e., Southeast Asian market. Therefore, we picked the Southeast Asian' emerging market, namely, Bangladesh IT industry, where not only IT goods but also services become significantly important.

We analyzed the current situation of Bangladesh IT market and seek the potentiality for Fujitsu business expansion in this market. The problems identified in this market are lengthy process, i.e., high lead-time, margin on margin in every step, and less reliability of goods and services. As a result, majority of customers are not happy and want more valuable goods and services, including consulting, training, maintenance services and so 
on. In this circumstance, Fujitsu can approach to Bangladesh IT market by appropriate response to the customer needs. The article suggested the firm how they can penetrate and move toward this market by giving appropriate response to the customer needs in different phases. The article also proposed a conceptual model of partnership alliance and shows how it can create values for Fujitsu, local partner and customers as well.

The research result can be used to design services with existing products required by customers, and help companies to mitigate the customer needs in Bangladesh IT market. The expected benefits from this research are to help enterprise managers and decision makers to response the current market needs properly and take right strategy toward entering Bangladesh IT market.

Since our empirical study analysed data collected from one firm, i.e., Fujitsu limited and Bangladesh IT industry, it would be interesting and valuable to conduct similar surveys through number of firms and other emerging country and / or regions for comparative studies. Furthermore, we may extend our study in the future by increasing sample industries, such as telecommunication, electronics, automobiles, and so on. In the future is important to make further research on developing service-oriented culture in Bangladesh IT market where providers and customers are becoming a value co-creator. How Japanese IT firms can penetrate other emerging country by using its capabilities 'know how'?

\section{References}

Annual Report on The Japanese Economy and Public Finance, July 2004, Cabinet Office, Government of Japan, Retrieved from: http://www5.cao.go.jp/zenbun/wp-e/wpje04/04-00301. html

Bangladesh Association of Software and Information Services (BASIS), http://www.basis.org.bd

Bangladesh Computer Society, Retrieved from: http://www. bcsbd.org.bd/

Datasoft Systems Bangladesh Limited, Retrieved from: http://www.datasoft-bd.com/

Fujitsu Annual Report (2012), Year ended March 31, 2012 , Retrieved from: http://www.fujitsu.com/downloads/IR/ annual/ 2012/all.pdf

Gebauer, H. \& friedli, T. (2005), Behavioural implications of the transition process from products to services, Journal of Business \& Industrial Marketing, 20(2), 70-80.

Goldman Sachs (2005), Assets Management, The Next 11, Retrieved from: http://www.goldmansachs.com/gsam/ advisors/products/growth_markets/n11/

Gartner Inc., http://www.gartner.com/technology/home.jsp

Mathe, H. \& SStaudacher, R. (2004), "Innovative services that reinvent manufacturing", paper presented at IMS International Forum, Cernobbio

Neely, A. (2007), The servitization of manufacturing: An analysis of global trends, paper presented at 14th Euro OMA Conference, Ankara

Oliva, R. \& Kallenberg, R (2003) "Managing the transition from products to services, International Journal of service Industry Management, 14(2).

International Data Corporation (IDC), Retrieved from: http://www.idc.com/

Spectrum Engineering Consortium Limited, Retrieved from: http://www.spectrum-bd.com/

Vandermerwe, S. \& Rada, J. (1988), "Servitization of Business: adding value by adding services", European Management Journal, 6(4) 